\title{
Frans de Waal, Matpy i filozofowie. Skąd pochodzi moralność?, tłum. Bartosz Brożek, Michał Furman, Copernicus Center Press, Kraków 2013, ss. 252.
}

Profesor Fras de Waal, autor prezentowanej publikacji jest holenderskim etologiem i prymatologiem, wykładowcą akademickim oraz członkiem wielu prestiżowych stowarzyszeń, m.in. Królewskiej Holenderskiej Akademii Sztuk i Nauk oraz Narodowej Akademii Nauk Stanów Zjednoczonych. Jego badania naukowe koncentrują się wokół ssaków naczelnych, w szczególności szympansów. Swoje badania rozpoczął sześcioletnim projektem obserwacji zachowania szympansów w niewoli, prowadzonym w ogrodzie zoologicznym w holenderskim Arnhem czego owocem była książka „Primates and Philosophers”, która jednak nie ukazała się w języku polskim.

Dotychczasowe publikacje tego autora skupiały dotyczyły problematyki socjobiologicznej w kontekście ewolucji naczelnych. Prezentowana książka kontynuuje tego typu rozważania. Formalnie została podzielona na trzy części: I. Ewolucja moralności, II. Komentarze, III. Odpowiedzi na komentarze, poprzedzone wprowadzeniem autorstwa innych uczonych. To stanowi również pierwszą wątpliwość co do książki de Waala gdyż ponad trzecia jej część wywiodła się spod pióra innych autorów.

Już na wstępie autor przywołuje starożytne przysłowie „człowiek człowiekowi wilkiem" stwierdzając, że obraża ona zwierzęta, gdyż psowate są bardzo towarzyskie a jednocześnie zgadza się, że pasuje ono do ludzkiej natury, sugerując w ten sposób kierunek prowadzonego wywodu. Czytelnikom proponuje się dwa założenia wyjściowe - pierwsze z nich to „teoria fasady”, którą zdaniem de Walla jest cienką zasłoną społeczną, za którą kryje się niemoralna ludzka natura. Moralność ludzka zdaniem autora istnieje jedynie po to, 
by unikać kar, wykluczeń z grup społecznych i potępienia. Kwestia druga dotyczy rozstrzygnięcia problemu czy ludzka moralność jest zakorzeniona w naszej ewolucyjnej przeszłości. Autor rozpatruje obie te kwestie jednocześnie co wprowadza pewien zamęt. Uważa on, że nasi bliscy krewni w świecie przyrody przejawiają tendencje do zachowań moralnych zbliżonych ludziom. Da się tu dostrzec pewną niekonsekwencję - albo „teoria fasady”, albo ewolucyjna przeszłość naszej moralności, gdyż problemów tych nie sposób połączyć w sposób proponowany przez de Waala.

Co najmniej zaskakujące jest powołanie się na rawlsowską teorię umowy społecznej jako konieczności ukrycia okrucieństwa ludzkiej natury. Zdaniem autora pokazuje ona, że jesteśmy istotami aspołecznymi. Motywuje to „teorią fasady” czyli stwierdzeniem, że człowiek to naturalny egoistą. Trudno jednak wyobrazić sobie cały gatunek ludzki jako zbiorowość aspołeczną, gdyż to właśnie nasz gatunek kreuje pojmowanie społeczeństwa. Raczej nie było zamysłem J. Rawlsa, gdy przedstawiał swoją koncepcję, ewolucyjne podbudowywanie swoich założeń. Zarazem holenderski uczony stara się polemizować z R. Dawkinsem i T.H. Huxleyem, co może nieco dziwić każdy bowiem z tych uczonych jest zwolennikiem teorii ewolucji i korzysta z tych samych jej założeń co de Waal, oczywiście poza wspomnianą „teorią fasady”, przez co rozważania autora z ewolucjonizmem ma niewiele wspólnego.

Autor uważa, że współczucie jest cechą wspólną ludzi i zwierząt. Tak się dzieje również poza ramami rodzicielstwa zwierząt, gdzie także osobniki obce danego gatunku okazują sobie współczucie. Jako przykład podaje słonie, żyrafy i rzecz jasna szympansy. Nie przytacza jednak żadnych dowodów poza obserwacją i własnymi wnioskami opartymi na samej interpretacji tego, co zaobserwował. Dla przykładu, co umknęło Holendrowi, tygrysy i hipopotamy zabijają młode własnego gatunku niebędące ich potomstwem po to, by samica-matka była szybciej zdolna do kolejnej kopulacji. Tak też niewątpliwie „działa mechanizm ewolucji” gdyż samce wspomnianych gatunków chcą pozostawić na świecie jak najwięcej własnych genów a eliminować geny konkurentów. 
Poruszając problem emocji takich jak wdzięczność i oburzenie de Waal stwierdza, że świadczą one o egoizmie, gdyż wskazują jak dana jednostka funkcjonuje oraz jak by chciała być traktowana. Autor uważa, że w związku z powyższym nie można rozważać ich w kategoriach moralności. Podkreśla również, że emocje winny być rozpatrywane na bardziej abstrakcyjnym poziomie, co może dziwić biorąc pod uwagę fakt, że takie dyspozycje przypisuje również zwierzętom, w szczególności naczelnym. Przy okazji czytelnik znajdzie również autorski opis empatii, która zdaniem Holendra da się zaobserwować również u szympansów oraz stanowi punkt wyjścia dla procesu uspołecznienia. Nie podał jednak czy chodzi o proces uspołecznienia wśród ludzi czy wśród wspomnianych małp, gdyż ich zachowania de Waal określa jako zwyczaje społeczne.

Za ważne naukowo uznać należy podane wyniki obserwacji małp człekokształtnych. Na podstawie własnych spostrzeżeń autor opisuje zwyczaje tych zwierząt a ich zachowaniom nadaje konkretne atrybuty. Czasem można odnieść wrażenie, że stara się przemawiać do czytelnika w ich imieniu. Jedna kilka akapitów dalej krytykuje obserwatorów np. żyraf twierdząc, że przedstawiają tylko obserwacje niepoparte innymi dowodami świadczącymi, że konkretne zachowanie świadczy o danych potrzebach czy nastrojach tych ssaków. Po raz kolejny można dostrzec skłonność holenderskiego profesora do faworyzowania małp człekokształtnych. Autor wyraźnie oddziela te naczelne od pozostałych zwierząt ukazując, że są istotami doskonalszymi od pozostałych przedstawicieli królestwa zwierząt.

Powracając do problemu emocji autor stara się także połączyć empatię z niepokojem. Stwierdza, że cierpienie innych budzi niepokój obserwującego cierpienie. Niepokój natomiast jest impulsem, którego człowiek nie potrafi kontrolować a ten rodzaj niekontrolowanej emocji nazywa empatią. Niepokój jest zatem ewolucyjnym odruchem a po nim dopiero następuje racjonalizacja tego odruchu czyli empatia atrybut obserwowany jedynie u ludzi i małp człekokształtnych.

Autor proponuje stosowanie terminu antroponegacjonizm, który konsekwentnie stosuje na łamach prezentowanej książki do porównywania zachowań ludzi i zwierząt. Jak sama nazwa wskazuje neguje 
w ten sposób wyższość moralną człowieka od pozostałych stworzeń. Przywołując wyniki własnych obserwacji de Waal zdaje się uwypuklać zbliżone zachowania ludzi i szympansów twierdząc, że zachowania obu gatunków należy rozpatrywać w kategoriach etycznych. $\mathrm{Na}$ uwagę zasługuje fakt, że autor egoizm ludzkich zachowań wywodzi od egoistycznych zachowań szympansów lecz nie popiera tego żadnymi dowodami poza stwierdzeniem, że wywodzimy z linii ewolucyjnej tych zwierząt a to jednak zbyt mało aby formułować tak daleko idące wnioski. Podkreślić należy, że większość wniosków pochodzi $\mathrm{z}$ badań autorskich ale przeprowadzonych $\mathrm{w}$ ogrodach zoologicznych, co stanowi naturalną barierę dla prowadzenia badań. Holender nie wspomina nic o przedsięwzięciach badawczych realizowanych w naturalnym środowisku tych naczelnych. Ponadto jego zdaniem naczelne powinny mieć szczególny status, gdyż są biologicznie najbliższymi krewnymi naszego gatunku - prowadzą podobne do naszego życie społeczne i emocjonalne oraz cechują się podobną inteligencją. Brak jednak jakiegokolwiek uzasadnienia takiego stanowiska poza samym przekonaniem autora. Na domiar tego autor stwierdza, że jest to pogląd antropocentryczny, co po raz kolejny udowadnia, że przydaje ssakom naczelnym atrybuty ludzkie.

Autor omawia także praktykę badań i eksperymentów prowadzonych na zwierzętach w celu poszukiwania skutecznych leków na ludzkie choroby. Stara się wykazać, że niemoralne jest prowadzenie takich przedsięwzięć na szympansach, ale za to śmiało można do tego wykorzystywać inne gatunki zwierząt, w tym również małp. Po raz kolejny stawiając znak równość między człowiekiem a szympansem de Waal proponuje by ten gatunek małp były poddawany jedynie takim badaniom, jakim mogą być poddawani ludzie.

Część dr5uga książki stanowią komentarze i polemiki R. Wrighta, Ch. Korsgaard, P. Kitchera oraz P. Singera. Zwrócić uwagę należy, że są to teksty dotyczące $\mathrm{z}$ reguły całej spuścizny naukowej de Waala a nie tylko książki, w której je zamieszczono. Większość z nich poddaje srogiej krytyce „teorię fasady” a właściwie jej interpretację oraz zbyt śmiałe porównywanie zwyczajów zwierząt z zachowaniem człowieka. Dla przykładu Ch. Korsgaard stwierdza, że moralność jest 
atrybutem ludzkim i stanowi o wyjątkowości ludzkiego działania. Podkreślić należy, że w większości odnosi się do publikacji de Waala „Polityka szympansów” a nie do prezentowanej książki. P. Singer jest podobnego zdania jednocześnie chwaląc de Waala za angażowanie się w walkę o prawa zwierzą, jednak daje się zauważyć, że uważa Holendra za więźnia swych przekonań.

Na powyższe polemiki i komentarze autor odpowiada zbiorczo w ostatnim z rozdziałów książki jednak czyni to jednak niezbyt udolnie. Interpretuje uwagi i postulaty komentatorów na własną korzyść, dając sobie tym samym możliwość wybrnięcia ze stawianych zarzutów, ale zarazem streszcza kilka swoich poprzednich książek, do których polemiki się odnosiły.

Podsumowując wrażenia z lektury trzeba stwierdzić, że książka może rozczarowywać. Bardzo trudno doszukać się w tym szkicu treści o charakterze filozoficznym. Niezrozumiałe jest dlaczego autor zdecydował na nadanie swojemu dziełu takiego właśnie tytułu. Treści bowiem są bliższe zagadnieniom socjobiologicznym zabarwionym elementami psychologii społecznej niż filozoficznym. Samo bowiem proste przedstawienie altruizmu psychologicznego u szympansów niewiele mówi o pochodzeniu czy jak woli de Waal, o ewolucyjnych korzeniach etyki. Niewiele nowego wprowadzają również próby rewidowania poglądów Darwina. Autor sam dyskredytuje głoszone w książce stanowisko przykładem kapucynki, która ciska przedmiotami w badacza, a gdy „pociski” jej się kończą, rzuca w niego małpą innego gatunku. Tymczasem można z góry założyć, że człowiek by nie rzucił w nikogo swoim towarzyszem i to nie z powodu braku sił na takie działanie, ale $\mathrm{z}$ uwagi na uwarunkowania moralne. Autor chciał przede wszystkim rozprawić się traktowaniem moralności jako atrybutu przynależnego jedynie ludziom. Z całą pewnością nie udało mu się tego dokonać i raczej nie zbliżył się nawet do tego celu.

Łukasz Moniuszko Instytut Filozofii, UZ 